\title{
Religious security in vietnam today
}

\author{
Lan Hien $\mathrm{Do}^{1, *}$ \\ ${ }^{1}$ Institute of Religion and Belief, Ho Chi Minh National Academy of Politics, 135 Nguyen Phong Sac \\ Str., Cau Giay District, Hanoi
}

\begin{abstract}
For a long time, social awareness still asserts that religion with a supernatural belief system will bring people peace and help believers face challenges of life. People who perform religious rituals will create a "mechanism" to fight stress, reduce psychological stress, and even cure illnesses. But another reality exists, religious beliefs can be a factor causing people to behave in the wrong way such as killing innocent people, committing suicide or threatening the right to life, the right to political, social stability, the right to religious freedom of others. Religion can become an opportunity, power to control human security, community security, social security, more extensively national security and ideological maintenance of that nation. Therefore, it is necessary to study the topic of religious security adequately with the extent of its influence. In this article, I will analyze the current situation of religious security in Vietnam by assessing the religious activities.
\end{abstract}

\section{Introduction}

The religious topic is concerned with not only the "sacred" and "ontological" issues of religion, but also religious security because religion is at the foundation of the current international order and greatly influences world peace. Religion is a set of factors (not to be missed) in national and international security, but not many governments put religious security on the forefront, religion is not closely integrated into security as it should be. The solidarity between religious security and political, economic, cultural, social and human security is a recognized fact. Economic, political and cultural factors can bring challenges to religious security, whereas religion will also be a factor that brings instability to economic, political and cultural security and moreover national security and the country's sustainable development. The current situation of religious security in Vietnam is not so much as a "red" alert. However, religious security in the world and in Vietnam is getting more and more complex. Increasing religious conflicts about not only religious freedom, but also political rights, economic rights and other human rights.

Addressing religious security requires not only just a single country but it is also an international matter. In order to ensure religious security in Vietnam, in my opinion, the factors that threaten religious security should be removed.

\footnotetext{
*Corresponding author: dolanhien67@gmail.com
} 


\section{Research Methods}

- The article uses textual analysis methods: collecting and systemizing published documents on national and international books as well as newspapers on religious security.

- The article uses quantitative research methods: using quantitative research data that has been acknowledged in previous scientific works to create a basis for general assessments of the situation of religious security in Vietnam today.

- The article uses analytical and synthesized method: based on analysis of existing facts and data to assess the situation of religious security in Vietnam today.

\section{Results}

\subsection{Concept of "Religious security"}

Security is a multi-meaning term understood as the ability to resist potential harms creating undesirable coercive change by external or internal forces and factors of the object. It is the ability to maintain safety against all threats.

Ensuring security, maintaining safety from threats can allow an individual or an organization to take any action including that it may affect or harm an individual or certain group of people considered to be a threat to security.

Subject of security can be a human being, a social group, an organization or any other entity or phenomenon.

Previously, the traditional approach to security was directed at the subjects of the state and the nation. The term "national security" is simply understood as protecting the country against military attacks, wars of aggression on territorial borders and armed demonstrations, terrorism, civil war in the country to protect political regimes, sovereignty and territorial integrity. Measures to protect national security often emphasize military, political and diplomatic measures.

Since the 90s (twentieth century), the trend of globalization, environmental degradation, climate change, terrorism, international crime and epidemics has been increasing, opening up new contents for security concept. Happening of an alternative approach to the traditional studies on security from military to non-military aspects, from the subjects of the state to the subjects of people and organizations. Threats to security have been extended to economic, political, cultural, religious and human factors. Non-traditional security term appears.

According to OSCE (Organization for Security and co-operation in Europe), security is fully and comprehensively understood as cooperation, equality, non-division of human rights in the fields of politics, military, economy, environment and human, ensuring security for all fields is considered of equal importance [OSCE, Freedom of Religion or Belief and Security, Policy Guidance, Published by the OSCE Office for Democratic Institutions and Human Rights (ODIHR). www.osce.org/odihr/2019].

Since OSCE is an organization of the European Office for Democracy and Human Rights, the security topic in terms of OSCE's understanding is related to issues of democracy and human rights, especially religious freedom. Accordingly, religious freedom is specifically recognized as one of the basic principles, an indispensable aspect in the concept of security. It emphasizes the link between security and complete respect for freedom of thought, conscience and religion. Peace and security are only achieved when religious freedom is guaranteed on the basis of recognition of religious diversity, the right to profess and practice of belief. Religious freedom is the foundation for a flourishing and sustainable society. Religious freedom contributes to respect, trust, understanding and 
equality of different ethnic groups. Therefore, it can make society more resilient to security threats [OSCE, Freedom of Religion or Belief and Security, Policy Guidance, Published by the OSCE Office for Democratic Institutions and Human Rights (ODIHR). www.osce.org/odihr/2019]. Religious freedom is also a means of mobilizing and facilitating positive resources of religious community to participate in social life. Unreasonable restrictions on religious freedom will obscure the potential of religion in building a society where security is guaranteed.

Thus, religious security is not an isolated concept associated only with religion, but it is related to political, economic, cultural, national and international security. Religious security is both a form of traditional security (related to political factors, state, military, riots, subversion, terrorism) and non-traditional security (non-military, non-local, non-state, related to the spirit, ideology, culture, psychology, emotions, people). Religious security is a component of national security, or in other words, national security covers many security elements, including religious security. Religion plays a "dual role" in the issue of national security, it can both create and promote national order by initiatives, ideas, even by the movement to fight for peace. But religion itself is the "catalyst" that triggers the "fuses" of conflicts, wars, terrorism, and mass murder. The link between religion and terrorism as well as war is a fact that has been well documented in recent decades in the world. In many cases, religion is the factor, the opportunity, the power to control human security, community security, social security,... more extensively national security. Although it can be exaggerated in many cases so that people become hostile to religion, the government becomes prejudiced, wary of religion and has completely forgotten the ability to use religion itself to resolve conflicts, preserve security and sustain national and international development.

In short, religious security is understood: (1) Being able to maintain religious stability, all religious activities are not disturbed, do not threaten the stability of life of people and the nation, as well as political institutions; (2) Religious organizations and governments have the ability to resist the potential harms affecting religious stability; (3) Factors threaten religious stability; (4) Forces, behavior and systems of measures to protect religious safety; (5) The beneficiary of religious security is a person or community (social groups), a religious organization, a government or state; (6) Factors that challenge religious security may come from outside religion, but may be from religion itself.

\subsection{Overview of the situation of religious security in Vietnam today}

The following assessments of areas related to religion show the level of religious security (safety) or religious insecurity (uncontrollable) in Vietnam today.

\subsubsection{Assessment of the level and needs of faith}

In the Documents and Resolutions of the Party and the State of Vietnam, it is said that religion is the spiritual needs of a part of the masses. However, the reality of religious life in Vietnam today shows that a large number of people have religious needs. At present, nearly 26 million people (accounting for $27 \%$ of the population) are followers of 16 religions [Buddhism, Catholicism, Protestantism, Islam, Cao Dai, Hoa Hao Buddhism, Tu an Hieu nghia, Buu son Ky huong, Minh su, Minh ly - Tam tong temple, Hieu nghia Ta lon Buddhism, Tinh do cu si Buddha, Cham Brahmin, Bahai, Mocmon (The Church of Jesus Christ of Latter-day Saints), the Complete Gospel Church of Vietnam] (recognized by the State) regularly participating in rituals and religious activities. More than 45 million Vietnamese (accounting for nearly $50 \%$ of the population) have taken refuge in the Three Jewels and also regularly participate in the practice of worshiping at Buddhist worship 
facilities or at private home (Worship at Home) [https://thuvienhoasen.org/a32746/thongke-so-luong-tin-do-phat-giao-tren-the-gioi]. Many people often go to the pagoda to listen to teaching on the Dharma, practice meditation to improve their health, cure diseases or find spiritual peace. $95 \%$ of the population are more or less engaged in ritual acts at religious worship facilities or at home. People tend to find "spiritual solutions" when they encounter obstacles and unhappiness in life. Forming a "religious market", religion is seen as a "commodity" product on the market, the consumers of religious "goods" are the believers, the suppliers of religious "goods" are monks and religious dignitaries. In the "free competition" market mechanism, religious dignitaries based on the religious needs of believers will constantly innovate and provide "new commodities" such as medical treatment, pray for dispelling bondholder's unjustice, for allaying various illnesses and ailments, for exorcising repetitive funeral, for assiting soul of the newly deceased, for eternal fovourable conjugal life, for offsprings, for position and wealth, fortelling fortune, foreseeing the good or bad days, good and ill luck... to stimulate people's "religious consumption" needs, promote the prosperity of their own religion and compete with other religions. The price of this "commodity" is not calculated according to the law of value, sometimes it is super costly and superprofitable but customers still voluntarily pay.

The religious belief of the people today are moving from passive to active. Particularly, in the group of people whose existential safety is threatened with a loss of job, personal property, house, relatives, work position as well as sickness, divorce, infertility, loneliness, they actively seek religions in order to be supported, advised, to improve their health, to heal, to relieve their frustration. People are willing to pay a not small "fixed" cost for their "consumption and enjoyment" of religion.

The believers today are not only the uneducated, the weak, the poor, the unfortunate, but also the educated, successful businessmen, party members, cadres, with the trend of rejuvenation.

In general, religious belief has a strong secular "fulcrum" (political, economic, social). Thus, religion is "possessing" opportunities and power to control spiritual security and human security, more extensively economic and cultural security in Vietnam today.

\subsubsection{The level of religious diversity}

In a short time (over the past one or two decades ), in Vietnam, the number of staterecognized religious organizations has increased 7-fold. In 1999, only 6 organizations belonging to 6 religions were recognized by the State (Buddhism, Catholicism, Protestantism, Islam, Cao Dai and Hoa Hao Buddhism) with about 14.7 million followers (about $19.4 \%$ of the population). In 2011, it increased to 34 officially recognized organizations belonging to 13 religious with about 25 million believers (accounting for $28.4 \%$ of the population). In 2019 , there were 43 organizations belonging to 16 religions that were registered to operateand were recognized as religious legal entities by the State, in addition to more than 100 new religious phenomena (not yet licensed and recognized by the State) is

operating [http://btgcp.gov.vn/Plus.aspx/vi/News/38/0/240/0/2263/Tinh_hinh_ton_giao_va_nhung_y eu_cau_dat_ra_voi_cong tac_ton_giao].

The most typical of religious diversity is the Protestant case. At the present time (2020), Protestantism in the world has about 300 sects and thousands of different Protestant organizations. Protestantism entered Vietnam quite late (in 1911), after half a century of presence in Vietnam (until 1975), the Protestant had 20 organizations and sects with about 550 chapters. In the next half century (2015), this number increased 4 times (more than 80 sects, 606 chapters and 4,757 groups) [1]. By 2019, only 11 Protestant denominations have been recognized and granted registration to operate by the State, more than 70 
denominations have not been recognized by the State but still operate normally [Summary Report on the work in 2018, the mission in 2019 of the State management on religion and belief of Vietnam (Government Committee for Religious Affairs)].

In particular,the forms of religious practice in private spaces appear (private homes, offices, community living areas in apartment buildings, cultural houses in villages/communes) instead of being present at religious worship facilities. These forms of ritual practice in this private space are the seeds of small, self-governing, spontaneous and non-organized religious groups, making it difficult for the state's religious management.

In general, the increase in the number of religious organizations and denominations; the proliferation of new religious denominations can enrich the religious life in Vietnam and satisfy the multidimensional religious needs of the believers, but it is a significant challenge for religious stability and social safety. On the religious side, the diversity of religious denominations and organizations, and the proliferation of new religious phenomena willcause conflict becauce they are competing to the previous ones to seek a stand, and wishing to equitably share the "religious market". On the State side, the diversity of religious sects places the state management agencies in a difficult position. This concerns them about religious harmony, national harmony and worries them about national security. Therefore, in many countries, governments often in the name of religious harmony and ensure national security have strict policies to prevent, not recognize, not grant operating registration for new religious groups (especially those imported from abroad), religious organizations (which have been recognized by the State) must guarantee the religious groups, their religious sects, strictly control all activities, all participants.

Religious diversity is an inevitable and dynamic trend of religions in order to create new, diversified "commodity products" to maximally satisfy the religious needs of the believers. Religious diversity entails religious competition, demands for legal status. This process will threaten religious and national security in Vietnam if this issue is not well controlled.

\subsubsection{Appearance of many new extreme religious phenomena}

Currently in Vietnam, in addition to 16 religions with 43 organizations and sects that have been recognized and granted operating registration by the State, there are still many new religious phenomena (imported from abroad into Vietnam) such as Falun Gong (China), Unification Church (USA), Om sai Baba (India), I-kuan Tao (China), Supreme Master Ching Hai (France), Aum (Japan). Hundreds of new (endogenous) religious phenomena have also begun to form, develop and attract followers, draw the attention of public opinion.

These new religions have names based on traditional Vietnamese religions and beliefs, but their beliefs and practices are strange. The "masters" of these new religions are often people with complex and abnormal mentality. The believers participating in these religions are often women, the weak, the disadvantaged and the sick. Joining these new religions, people can find ways to deal "immediately" with a part of the stalemate in their lives (such as illness, loneliness, infertility, divorce,...), relieve stress of hot topics in socio-political life (such as corruption, inequality, violation of democracy, human rights, unemployment, poverty, job loss, land loss, environmental pollution, epidemics, ...)

These new religious phenomena often use "magical" means to scare believers by using natural disasters, epidemics, or tribulations so that they have to pay money to the "masters" for worship ceremony in order to help (Vang Chu, Duong Van Minhreligion), aswell as to threaten if they do not pay, they will be crazy (Long Hoa Maitreya religion), or to offer worship to believers (Ho Chi Minh Gem Buddha religion). These new religion practice "lucrative" activities such as collecting fees for joining, selling scripture books and 
offerings (Long Hoa Maitreya religion, Ho Chi Minh Spirituality), making believers beg for alms (Luu Van Ty barefoot religion). Many people, who believe in new and strange religious phenomena, neglect their work, sell their properties, and spend time to worship, hoping to go to "Heaven" when natural disasters, floods, crop failures or epidemic occur (Vang Chu religion).

In general, new religions following extremist trends emphasize personal freedom, compete for a stand, replace traditional religions, and demand a fair share of religious "markets".They demand legal rights like traditional (old) religions, using the followers to force the government to recognize, to give them license in order to operate or to ignore them. It is very difficult for state management agencies in Vietnam to intervene directly in these religions because Vietnam's Constitution and Law stipulates the people's right to religious freedom. The Vietnamese State can only intervene indirectly in new religious phenomena through the judicial system or court when these religions violate the law, are sued and accused of violating security and order, endangering people's health, money, life and dignity.

In short, the emergence of new religious phenomena is inevitable, it satisfies the multidimensional religious needs of the people, satisfies democracy, freedom in religious choice. Most of the emerging religious phenomena in Vietnam (in recent years) have tended to be extremist, posing major challenges to: (1) spiritual security (pathological beliefs, rebellious mentally, morally,...); (2) economic security (enticing, seducing, intimidating believers to surrender their assets, money, neglect of production, business, labor, study); (3) religious security (competition with traditional/old religions, disrupting religious harmony); (4) social security (abuse of health, life, dignity, culture, customs, practices ...); (5) national security (propaganda against the Communist Party and State of Vietnam, inciting demonstrations, riots, subversion).

\subsubsection{Issues of land and worship facilities of religion}

In the past two decades, the issue of religious land in Vietnam has been quite complicated. Religious "hot spots" that cause social disorder are all related to religious land. Lawsuits, complaints and disputes related to religious land also account for a large proportion of religious lawsuits. According to incomplete statistics of the Department of Social Security (Ministry of Public Security), in 54 provinces and cities directly under the Central Government (over the past 2 decades), there have been over 2,000 land lawsuits involving religion (mainly reclaiming land previously borrowed, confiscated, requisitioned and nationalized by the State from 1954 to 1975). Large numbers of people gathering that cause political insecurity and social disorder and unsafetyness (in many areas) account for a large proportion of religious "hot spots". According to the statistics of the Government Committee for Religious Affairs, as of 2019, only 4 religions (Catholicism, Buddhism, Protestantism, Cao Dai) had a total of 723 lawsuits and disputes over religious land (Catholics - 430 cases, Buddhism - 196 cases, Cao Dai - 65 cases, Protestants - 32 cases) [The project "Surveying the real situation of the land, worship facilities of religious organizations in Vietnam today, solutions and recommendations, 2019" (Government Committee for Religious Affairs)].

Formerly individual belivers who filed a lawsuit against the authorities is now a religious official. They took the signatures of the people, mobilized a large number of followers to gather, protest, sabotage public assets, against law enforcement forces, arrest officials, smash public agencies and headquarters, block traffic. When the authorities have not resolved the matter, they called for the support of international organizations and expats throught social nets. A number of lawsuits have brought the issue of religious land in 
combination with the struggle for freedom, democracy, and the abolition of the Communist Party. The land issues have been transformed into socio-political issues.

In Vietnam, religious land is granted by the State (without collecting land use fees). After 1975, a series of religious facilities (previously granted) were subjects to "socialist reform", so the government took over, confiscated and requisitioned them. Some of religious land have been used for socio-economic development and national defense purposes. Some were encroached by the surrounding people.

According to Vietnamese law, religious land is granted by the State (without collecting land use fees), so religious organizations will not be allowed to transfer, donate, mortgage or trade. If they violate, they will be revoked. Religious land will not be compensated when the State revokes for national defense, security, socio-economic development purposes and national interests [Land Law No. 45/2013 / QH13, Articles 63, 64]. However, at present, religious organizations and individuals still transfer and trade religious land (in many forms) that are not controlled by the State and cannot be revoked. When reclaiming religious land for use in socio-economic development and national interests, the State still has to compensate in the form of replacing it with another land (usually wider). Religious organizations often make it difficult for land revoking by refusing to return,asking the State to compensate as required.

Table 1. The percentage of believers, the number of places of worship and the area of religious land owned (in some big cities) shows the irrationality and disparity in land fund for religion among cities.

\begin{tabular}{|c|c|c|c|}
\hline Cities & Believers & Places of worship & Religious land in use \\
\hline Ha Noi & 843,282 & 1,664 & $426.6 \mathrm{ha}$ \\
\hline Bac Ninh & 132,813 & 632 & $170 \mathrm{ha}$ \\
\hline Hai Phong & 403,000 & 739 & $292.9 \mathrm{ha}$ \\
\hline Ninh Binh & 234,204 & 685 & $283.2 \mathrm{ha}$ \\
\hline Nam Đinh & 623,800 & 1,505 & $2.332 .7 \mathrm{ha}$ \\
\hline Ninh Thuan & 254,000 & 217 & $78.67 \mathrm{ha}$ \\
\hline Nghe An & 375,000 & 415 & $263.6 \mathrm{ha}$ \\
\hline Ho Chi Minh & $3,956,685$ & 2,157 & $357.8 \mathrm{ha}$ \\
\hline
\end{tabular}

Caption of the table 1: Report No. 379-BC/BDVTW, Summary of 10-year implementation of Designation 1940/2008/CT-TTg of the Prime Minister on houses and land related to religion.

Table 2.The increase in the number of places for worshipping of some typical religions in Vietnam (within 10 years from 2003 to 2013) shows the number of irrational increasing places of worship among religions.

\begin{tabular}{|c|c|c|c|c|}
\hline Religions & \multicolumn{2}{|c|}{ Believers } & \multicolumn{2}{c|}{ Places of worship } \\
\hline & 2003 & 2013 & 2003 & 2013 \\
\hline Buddhism & 9.063 .638 & 13.811 .481 & 13.476 & 17.912 \\
\hline Catholic & 5.512 .287 & 6.623 .481 & 5.860 & 7.445 \\
\hline Protestantism & 582.438 & 932.326 & 226 & 599 \\
\hline Cao Dai & 811.903 & 1.086 .349 & 907 & 1.265 \\
\hline Hoa Hao & 1.218 .137 & 1.392 .067 & 27 & 60 \\
\hline Islamic & 65.597 & 77.275 & 75 & 80 \\
\hline
\end{tabular}

Caption of the table 2: Report No. 379-BC/BDVTW, Summary of 10-year implementation of Designation 1940/2008/CT-TTg of the Prime Minister on houses and land related to religion.

The following statistics on the number of religious worship facilities and the number of educational institutions in Vietnam also show the irrationality of the issue regarding religious land. Currently, Vietnam has nearly 26 million religious believers but there are 28,000 worshiping facilities. Meanwhile, Vietnam has nearly 24 million teenagers (ages 1- 
15) but only has 2,402 preschools and primary schools (including people-founded and private schools) [https://danso.org/viet-nam/].

Nowaday in Vietnam, the investment in building religious worship facilities for business purposes and group interests is increasingly evident. Social networks in Vietnam use the term "religious joint stock company" or "BOT temple"(Build-Operate-Transfer Temple) to name the recent pagoda constructions in Vietnam such as Bai Dinh pagoda, Ba Vang pagoda, Tam Chuc pagoda... Believers and religious organizations build pagodas, holy temples, churches, statues, bells, and mugs that are more expensive. The construction of large-scale worshiping facilities compels individuals and religious organizations to call for a huge source of money to socialize investment, using large quantities of precious and rare timber, gold and silver minerals. Meanwhile, in Vietnam people (in remote, mountainous areas) still live in poverty, homelessness, cramped house. Additionally transport infrastructure, roads, bridges, schools, hospitals are still very modest.Monks took the construction of worship facilities to show off their prestige, leading to disputes over the right to manage the worship facilities, causing religious disunity within the country, worsening the situation of religious security in Vietnam today.

In general, the issue of land and religious worship facilities in Vietnam is a challenge for religious security and national security. If the lawsuits are not resolved satisfactorily, it is easy to create "colour revolution" and "street revolutions" to overthrow the government as happened in some countries like Serbia (2000), Georgia (2003), Ukraine (2004), Kyrgyzstan (2005), Lebanon (2005), Kuwait (2005). The Vietnamese government should not "ignore" and "overlook" a paradox: trillions VND are ready to invest in building temples instead of investing in the construction of schools, hospitals, bridges and roads. Vietnam is a secular country, the proportion of people with religion only accounts for $1 / 3$ of the population, but it boasts about many of the largest temples rather than the greatest bridges, the most modern railways and highway or the most civilized university and hospital in the world.

The above paradox is the most recognizable manifestation of religious change in Vietnam in recent years. That transformation signals a religious revival or a religious impairment. This question related to religious security and national security is put out for both the State and the Church and they need to answer.

\subsubsection{Social-oriented religious activities deeply penetrate the secular life and hidden many complex political - social issues}

Currently, religious activities are transforming from "spiritual salvation" into "realistic relief" with the motto "If society does not fulfill its duties to the community, then the Church will join in and replace it". Religious organizations compete with private and state organizations in vocational activities, vocational training, medical treatment, detoxification, humanitarian charity, social protection, nurturing orphans, caring for helpless elderly and HIV people,... to attract and bind followers.

Religion developes economic, social activities to promote prestige. Appeared "religious corporation", believers of the same religion will set up an association and do business together. People who follow the religion are satisfied not only their spiritual needs, but also their economic goals which is getting rich.

Religions are preparing plan and conditions to propose to the Vietnamese government which will allow participation in social-professional activities such as charity, humanitarian, social security, environmental protection, legal advice,... and public service activities such as education - training, medical care, ...

"Cross-border" missionary activities are performed online, via social networks, Internet, facebook. Religious activities of foreigners coming to Vietnam by means oftraveling, 
preaching, evangelizing in believers' private houses in the form of club for the elderly, charity club and gathering places for believers (no registered with competent state agencies) are increasing and getting out of control.

Religionization of civil matters (formosa event, special economic zone law, cyber security law, BOT fee collection...); politicization religious issues (Vietnam Inter-religious Council, Unified Buddhist Church, Pure Hoa Hao Buddhism,...); Taking advantage of diplomatic channels and international press interviews to incorrectly reflect religious situation and policies of the State of Vietnam; Establishing opposing political organizations to provoke protests, riots, subversion and autonomy (De ga Protestantism, Top Khmer Nam tong Buddhism, etc.).

These religionorganizations have internationalized religious issues in the form of assessing the extent of Vietnam's religious freedom, declared that Vietnam restricts and prohibits religious people, prevented dignitaries and followers from doing religious activities to lower the prestige and leading role of the Communist Party.These international misunderstandings about Vietnam lead to restrictions on relations, economic cooperation, capital lending or aid, restriction of visas for Vietnamese people into EU-US countries. They require the United Nations Human Rights organization to have an inspection of Vietnam's religious freedom issues.

The anti-Vietnamese forces, through the local churches, through the activities of nongovernmental organizations, through diplomatic activities and tourism have directly met and impacted on the heads of religions, surveyed the situation and provided support (money, means and training) for local religions in order to establish the political and social forces in opposition to the Communist Party. Nurturing and directing dissatisfied and disadvantaged forces in the country cause disturbance, create religious "hotspots" that destabilize political and economic security, make people confused and reduce the prestige of the Communist Party, weakening the local governments, holding the masses of believers, gradually separating them from the influence of local governments.

Taking advantage of religious-ethnic issues to incite separatist and autonomous ideology (typical in 3 regions: Central Highlands, Northwestern region, Southwest region), destabilizing religious security, political security and national security.

In general, religious activities in Vietnam (after 1986 up to now) have moved out of worship and spiritual space, penetrating deeply into social life to strengthenbelief, orthodoxy and compete with other religions. In the process to penetrate deeply into social life, religion inevitably wants to "replace" the secular value system, entice the masses, assert its orthodoxy, sometimes religions exploit hot issues of socio-political life such as corruption,society's vices, mistakes in the economic and cultural policies of the State, to a certain extent, they are social criticism the government needs to listen to. However, the Government should not "ignore" the reason behind religious politicization: the gap between rich and poor; human rights violation, social injustice; low-educated people, backwardness; poor social security; international political issues.

\section{Conclution}

Basically, religious security in Vietnam today is still under control. However, the threat of religious security and national security in Vietnam can still occur with the above "scenarios". For a long time, Vietnam's resources to ensure national security have tended to be allocated to political (regime), economic (production, national resources) issues. Meanwhile, the resources to ensure human and religious security are somewhat not adequate. In the current context, religious security needs to be expanded in many aspects: equality, human rights, democracy, corruption, poverty, housing, employment, epidemics, social prejudice, pollution of natural - social environment, crime,... Vietnam may have 
different priorities in a series of security issues mentioned above, but in general, there should be a general strategy and policy for the key issues such as poverty reduction, job creation, equality of economic opportunities for people, social resources, human resources and natural resources for sustainable development. In the current context, religious security can be achieved through strengthening democracy, human rights and harmonizing all people's needs (including religious needs). Religion can be an external cause that "obscures" the basic causes of unequal treatment, mistakes and failures of State policies that have caused conflicts in the name of protecting rights of religious freedom, but it is more related to political rights, economic rights, and human rights than religious rights.

\section{References}

1. Nguyen Thanh Xuan, Journal of Political Theory 6, 103 (2019)

2. S.E. Meyer, The Review of Faith \& International Affairs 6(3), 3-7 (2008) DOI: $10.1080 / 15570274.2008 .9523346$

3. C. Seiple, Memo to the state: religion and security 5(1), 39-42 (2007) doi: 10.1080/15570274.2007.9523276

4. M. Brill Olcott, The Review of Faith \& International Affairs 15(3), 24-34 (2017) DOI: 10.1080/15570274.2017.1354473

5. Ch. Marsh, The Review of Faith \& International Affairs 14(1), 66-79 (2016) DOI: 10.1080/15570274.2016.1145474

6. S. Kaufman, Modern Hatreds: The Symbolic Politics of Ethnic War. Ithaca (Cornell University Press, NY, 2001)

7. Ch. Marsh, Nationalities Papers 35(5), 811-830 (2007)

8. Ch. Marsh, Religion and the State in Russia and China: Suppression, Survival, and Revival (Continuum, New York, 2011)

9. A. Mc Gregor, The Jamestown Monitor-Chechnya Weekly 7(4) (2006) http://www.jamestown.org/chechnya_weekly

10. P. Murphy, The Wolves of Islam: Russia and the Faces of Chechen Terror (Potomoc Books, Dulles, VA, 2004)

11. J. Haynes, The Review of Faith \& International Affairs 17(1), 11-23 (2019) DOI: 10.1080/15570274.2019.1570755

12. M. Beissinger, Contemporary European History 18(3), 331-347 (2009) 